\title{
Teaching IT in Secondary Education through Problem- Based Learning Could be Really Beneficial
}

\author{
Georgouli Ekaterini \\ Professor \\ Ag.Spyridona, 122 10, Egaleo \\ Athens, Greece \\ $+302105385325$ \\ kgeor@teiath.gr
}

\author{
Bakoyannis Spyros \\ Assistant Professor \\ Ag.Spyridona, 122 10, Egaleo \\ Athens, Greece \\ $+302105385325$ \\ sbakogia@epy.gr
}

\author{
Giannakoulias Panagiotis \\ Postgraduate Student \\ Derigny 28-30, 104 34, Victoria, \\ Athens, Greece \\ +302108212624 \\ kontologis@mail.gr
}

\begin{abstract}
This article attempts to stress the need for extended research on the use of constnuctivist's elements for the teaching of Information Technology in Secondary Education. In our case study, we tried to draw conclusions by questioning adolescents for their Problem-Based Leaming experience during a threemonth Internet-Programming course.
\end{abstract}

\section{Categories and Subject Descriptors}

K.3.2 [Computers and Education]: Computer and Information Science Education - Computer science education

\section{General Terms}

Experimentation.

\section{Keywords}

Problem-Based Learning (PBL), Constructivism, Research.

\section{INTRODUCTION}

There is an increasing number of IT educators claiming that in a science where the occasional "contemporary" educational subjects change rapidly, what counts most is not the subject itself but the didactic procedure followed. (1] The Problem-Based Learning approach of education is a well-known constructivist's method that, in the last few years, has been growing as a possible altemative to the traditional approaches for Computer Science Studies. Many universities have already implemented the "new" methodology, while others are actually on the process of adoption. [2] Yet, among the various concerns faced by the pioneers, the students' reluctance to change their traditional perspective of the educational procedure is viewed as a major obstacle.

\section{THE RESEARCH}

A resolution to the above predicament requires a radical reformation of students' educational mentality, which could more conveniently be achieved during the initial stages of the

Copyright is held by the authoj/owner(s). ITiCSE' 03 , June 30-July 2, 2003, Thessaloniki, Greece ACM 1-58113-672-2/03/0006.
Secondary educational environment. Having been based on this hypothesis, we conducted a three-month research project with the participation of three high-school classes. The students experienced PBL by learning Internet-Programming through an ample project (the design of their School's web page). Taking guidance of previous implementations of PBL methodology [3], we tried to follow its principles and limit the range of modifications. Besides, the original goal of this research was to estimate the potentials of an extensive PBL implementation in Secondary Education for IT education. Eventually, the results collected by questioning students, state confidentially that such an attempt would worth our efforts. The questionnaires filled in by the teachers, however, were less optimistic. Nevertheless, both, students and teachers, agree that the current educational methods are not able to provide learners with the skills required by IT.

\section{CONCLUSION}

The reasonable anxiety of those claiming that self-directed didactic methods do not fit to teenagers should not diminish the importance of general accepted notions which sustain the necessity for further research on the proposed area. It was proved by this research that teenagers tend to enjoy constructivism and PBL as playful learning. Meanwhile, students of this age view the latest technology much more as a "toy" to be discovered, and less as an additional subject to be learned. Furthermore, the extent of IT subjects that a high-school class explores is not so deep, in a way that it can be easily taught using none of the traditional techniques. Last but not least, pupils are the most flexible of all learners in steering towards a new didactic style. Therefore, teaching new technologies to new crops of conventional students using modern methods does not appear much of an unreachable task. High-school classrooms and IT education offer unique opportunities to overcome the erroneous view of education and benefit from the advantages of student-centered learning.

\section{REFERENCES}

[1]L. Uden and A. Dix. Lifelong Learning for Software Engineers.http://www.hcibook.com/alan/papers/wcc-pbl2000/wcc-pbl-2000.pdf

[2]T. Greening, J. Kay and J.H. Kingston. Trialing a ProblemBased Learning Approach to First Year Computer Science. http://www.cs.su.oz.au/ jeff/pbltrial.ps

[3]D. Boud and G. Feletti. The Challenge of Problem-Based Learning. Kogan Page, 1991. 